\title{
DETERMINASI DISIPLIN BELAJAR DAN INTERAKSI SOSIAL TERHADAP PEMAHAMAN KONSEP IPS SISWA KELAS V
}

\author{
I Putu Bagus Juni Arta Negara1, Ni Wayan Suniasih1, I Wayan Sujana² \\ 1 Jurusan Pendidikan Dasar, Universitas Pendidikan Ganesha, Singaraja, Indonesia \\ ${ }_{2}^{2}$ Jurusan Pendidikan Guru Sekolah Dasar, Universitas Pendidikan Ganesha, Singaraja, Indonesia
}

\begin{abstract}
Abstrak
Penelitian ini bertujuan untuk mengetahui (1) pengaruh yang signifikan disiplin belajar terhadap pemahaman konsep IPS dan besaran determinasinya (2) pengaruh yang signifikan interaksi sosial terhadap pemahaman konsep IPS dan besaran determinasinya (3) pengaruh yang signifikan disiplin belajar dan interaksi sosial terhadap pemahaman konsep IPS siswa kelas V Gugus I Gusti Ngurah Jelantik Denpasar Utara tahun ajaran 2018/2019 dan besaran determinasinya. Jenis penelitian ini adalah penelitian ex post facto, dengan teknik korelasional. Populasi penelitian ini adalah seluruh siswa kelas V Gugus I Gusti Ngurah Jelantik yang berjumlah 264 orang dengan sampel 149 yang ditentukan dengan teknik proposional random sampling. Data pemahaman konsep IPS diperoleh dari tes uraian sedangkan disiplin belajar dan interaksi sosial diperoleh dengan menggunakan angket. Data tersebut dianalisis menggunakan analisis regresi linier sederhana dan analisis regresi linier ganda yang sebelumnya telah dilakukan uji prasyarat analisisnya. Analisis data menunjukkan (1) terdapat pengaruh yang signifikan disiplin belajar terhadap pemahaman konsep IPS yang dibuktikan berdasarkan $\mathrm{F}_{\text {hitung }}=$ $4,389>\mathrm{F}_{\text {tabel }}=3,91$ dengan determinasi sebesar 2,9\% (2) terdapat pengaruh yang signifikan interaksi sosial terhadap pemahaman konsep IPS siswa yang dibuktikan berdasarkan $F_{\text {hitung }}=4,64>F_{\text {tabel }}=3,91$ dengan determinasi sebesar 3,1\% (3) terdapat pengaruh yang signifikan disiplin belajar dan interaksi sosial terhadap pemahaman konsep IPS yang dibuktikan dengan $\mathrm{F}_{\text {hitung }}=4,12>\mathrm{F}_{\text {tabel }}=3,06$ dengan determinasi sebesar 5,3\%. Saran kepada peneliti lain hasil penelitian ini dapat dijadikan salah satu refrensi dalam bidang pendidikan untuk mendalami objek penelitian yang sejenis.

\author{
Keywords: \\ disiplin, interaksi, \\ pemahaman konsep IPS
}

\section{Pendahuluan}

Pendidikan merupakan hal yang sangat penting sebagai pondasi kehidupan seseorang. Pendidikan dapat diperoleh baik secara formal dan non formal. Pendidikan memiliki peran yang sangat penting dalam mencerdaskan anak dan membangun kreatifitas dan karakter anak untuk bangsa yang lebih baik. Permendikbud Nomor 22 tahun 2016 tentang standar proses menyatakan proses pembelajaran pada satuan pendidikan diselenggarakan secara interaktif, inspiratif, menyenangkan, menantang, memotivasi peserta didik untuk berpartisipasi aktif, serta memberikan ruang yang cukup bagi prakarsa, kreativitas, dan kemandirian sesuai dengan bakat, minat, dan perkembangan fisik serta psikologis peserta didik. Tingkat satuan pendidikan yang dianggap sebagai dasar pendidikan adalah sekolah dasar.

Pendidikan disekolah dasar dilakukan untuk meningkatkan pengetahuan siswa. Maju mundurnya pengetahuan anak didik ditentukan oleh seberapa besar kemampuan anak didik dalam mengemukakan pendapatnya terhadap suatu objek. Cara yang dapat digunakan untuk mengetahuinya yaitu dengan hasil belajar siswa. Hasil belajar adalah kemampuan yang diperoleh siswa setelah melalui kegiatan belajar untuk mengetahui tingkat keberhasilan siswa dalam mempelajari materi pelajaran disekolah (Susanto, 2013). Keberhasilan siswa dalam belajar bisa terjadi akibat pengetahuan yang memadai tentang pemahaman konsep dalam teori-teori tertentu. Menurut Bloom (dalam Susanto, 2013:6) "pemahaman diartikan sebagai 
kemampuan untuk, menyerap arti dari materi atau bahan yang dipelajarinya". Sardiman (2016:42) mengungkapkan bahwa "pemahaman atau comprehension dapat diartikan sebagai menguasai sesuatu dengan pikiran", dari pernyataan tersebut dapat disimpulkan bahwa pemahaman adalah kemampuan seseorang dalam menerjemahkan atau menyerap arti dari materi untuk dikuasai.

Menurut Susanto (2013:8) konsep merupakan "sesuatu yang telah melekat dalam hati seseorang dan tergambar dalam pikiran, gagasan, atau suatu pengertian". Thobroni (2015:23) mendefinisikan konsep sebagai "ide atau pengertian umum yang disusun dengan kata, simbol dan tanda", dari pengertian tersebut dapat disimpulkan konsep merupakan sesuatu yang tergambar dalam pikiran, gagasan, atau suatu pengertian yang disusun dengan kata, simbol, dan tanda. Aspek kognitif siswa dapat dilihat salah satu caranya dengan mengetahui pemahaman konsep siswa tersebut. Kemampuan pemahaman konsep merupakan landasan penting untuk berpikir dalam menyelesaikan permasalahan (Ningsih, 2017). Berdasarkan pengertian para tokoh tersebut, dapat disimpulkan pemahaman konsep adalah kemampuan untuk menyerap arti atau mengungkapkan kembali suatu materi yang diperoleh untuk menjadikannya gagasan atau suatu pemikiran yang bersifat melekat.

Pemahaman konsep tentang teori-teori banyak di jelaskan pada pemahaman konsep IPS. Berdasarkan Permendikbud Nomor 21 Tahun 2016 tentang standar isi menyatakan IPS adalah perilaku sosial dan budaya dalam konsep ruang, waktu dan aktifitas manusia untuk mengeksplorasi mengenai kehidupan sehingga dapat mencerminkan jati diri bangsa. Menurut Sardjiyo (2014:1.26) "IPS adalah bidang studi yang mempelajari, menelaah, menganalisis gejala dan masalah sosial di masyarakat dengan meninjau dari berbagai aspek kehidupan atau satu perpaduan". Menurut Gunawan (2013:38) IPS disebut sebagai "bidang keilmuan yang sangat dinamis, karena mempelajari keadaan masyarakat yang cepat perkembangannya". Berdasarkan uraian tersebut dapat disimpulkan bahwa IPS adalah suatu ilmu yang mengkaji suatu peristiwa yang terjadi dikehidupan manusia dalam dimensi ruang dan waktu yang cepat perkembangannya dan juga menyangkut tentang antropologi, ekonomi, hukum, filsafat, ilmu politik, sosiologi, agama serta psikologi. Dalam mempelajari berbagai hal semua harus didasari oleh tujuan yang ditentukan, dan apa hasil yang dapat diperoleh dalam melakukan hal mengenai hal dalam IPS. tujuan dari pendidikan IPS antara lain: pertama, memberikan pengalaman pengetahuan terhadap siswa tentang kehidupan bermasyarakat dan lingkungan. Kedua, memberikan suatu kemampuan dasar untuk bisa berfikir logis dan kritis dalam mengidentifikasi, menganalisis, dan menyusun alternatif pemecahan masalah sosial yang terjadi dalam kehidupan di masyarakat. Ketiga, memberikan pengalaman bagaimana berkomunikasi yang baik dan berinteraksi yang baik dalam kehidupan bermasyarakat. Keempat, memberikan rasa kesadaran terhadap nilai - nilai sosial, pemanfaatan lingkungan hidup yang menjadi bagian dari kehidupan. Kelima, memberikan siswa suatu kesempatan untuk ikut berperan serta dalam berkehidupan bermasyarakat.

Berdasarkan pengertian tersebut pemahaman konsep IPS dapat disimpulkan sebagai kemampuan untuk menyerap arti dari gejala dan masalah sosial dalam masyarakat dengan meninjau dari berbagai aspek agar bisa menjadi suatu pemikiran, jadi jika siswa lebih dalam mengerti tentang pemahaman konsep tersebut maka siswa tersebut akan lebih cepat mengerti tentang konsep-konsep yang dipelajari.

Persoalan mengenai pemahaman konsep IPS mencakup bagaimana cara siswa agar bisa mendalami teori dalam melakukan pembelajaran yang mengharuskan siswa mengerti tentang konsep dari IPS, ini dikarenakan berbedanya kemampuan penalaran antara siswa satu dengan siswa yang lainnya. Peningkatkan pemahaman konsep IPS dalam diri siswa perlu dilakukan pendidikan secara lebih inovatif dan juga interaktif agar siswa dapat fokus terhadap materi pelajaran yang diberikan. Hal lain yang mendasari pemahaman siswa dapat dilihat dari cara belajar siswa, pergaulan siswa, kegiatan siswa sehari-hari, keaktifan siswa dalam melakukan kegiatan belajar mengajar di kelas, dan tanggungjawabnya sebagai seorang pelajar. Selain itu, terdapat faktor lain yang mempengaruhi penurunan pengetahuan siswa tersebut yaitu disiplin belajar dan interaksi sosial. 
Seseorang yang ingin sukses dalam melakukan sesuatu memerlukan kedisiplinan dalam melakukan hal tersebut. Menurut Moeliono (dalam Darmadi, 2017:325) "displin adalah ketaatan (kepatuhan) kepada peraturan tata tertib, aturan atau norma dan lain sebagainya". Dalam Kamus Besar Bahasa Indonesia (2004:36) "disiplin merupakan tata tertib, ketaatan atau kepatuhan pada peraturan (tata tertib)", dari uraian tersebut dapat disimpulkan disiplin adalah kepatuhan atau ketaatan seseorang dalam mematuhi peraturan-peraturan dengan senang hati.

Seseorang dalam menjalani hidup perlu melakukan suatu hal untuk mengetahui apa saja yang ada didalam dunia ini, proses mengetahui tersebut biasa dinamakan belajar. Jika seorang tersebut sudah bisa belajar untuk mengenal lingkungan maka orang itu tidak akan mudah diperdaya oleh orang banyak, ini dikarenakan orang tersebut sudah mengetahuinya terlebih dahulu. Maka dari itu belajar sangat perlu dilakukan. Menurut Susanto (2013:4) "belajar adalah suatu aktivitas yang dilakukan seseorang dengan sengaja dalam keadaan sadar untuk memperoleh suatu konsep, pemahaman, atau pengetahuan baru sehingga memungkinkan seseorang terjadinya perubahan perilaku". Darmadi (2017:272) mengungkapkan bahwa "belajar merupakan proses dasar dari perkembangan hidup manusia, dengan belajar manusia melakukan perubahan-perubahan kualitatif individu sehingga tingkah lakunya berkembang". Menurut pengertian para ahli tersebut disimpulkan belajar adalah suatu proses perubahan reaksi terhadap lingkungan yang dilakukan dalam keadaan sadar untuk memperoleh suatu pengetahuan yang baru sehingga memungkinkan seseorang merubah perilakunya sehingga tingkah lakunya berkembang.

Dalam melakukan pembelajaran diperlukan ketekunan agar bisa mencapai hal yang diinginkan dengan sempurna maka dari itu, disiplin belajar sangat diperlukan dalam belajar. Disiplin belajar dapat dilihat dari ketaatan (kepatuhan siswa) terhadap aturan (tata tertib) yang berkaitan dengan kegiatan belajar mengajar disekolah (Darmadi, 2017). Menurut Anjarani (2016) disiplin belajar adalah serangkaian sikap tingkah laku siswa yang menunjukan ketaatan atau kepatuhannya untuk belajar secara teratur baik di sekolah maupun di rumah atas dasar kesadaran dirinya untuk belajar tanpa adanya paksaan.

Berdasarkan uraian tersebut dapat disimpulkan bahwa disiplin belajar adalah sikap tanggung jawab dalam melakukan sesuatu perubahan atau kegiatan reaksi yang mencakup pengetahuan, kecakapan dan tingkah laku yang didapatkan melalui sebuah latihan. Menurut Darmadi (2017:326) ada lima faktor yang mempengaruhi disiplin siswa dalam belajar atau disiplin belajar yaitu: keteladanan, kewibawaan, anak, hukuman dan ganjaran, serta lingkungan.

Disiplin belajar siswa sangat berpengaruh terhadap pemahaman konsep IPS siswa, ini dikarenakan jika siswa tidak bisa menaati peraturan yang ada disekolah maka akan menyebabkan situasi dalam pembelajaran tidak kondusif. Pada umumnya disiplin belajar diukur dengan menggunakan beberapa indikator. Daryanto (2013: 135) menjelaskan indikator disiplin di sekolah dan di kelas. Indikator di sekolah meliputi: (1) memiliki catatan kehadiran, (2) memberikan penghargaan kepada warga sekolah yang disiplin, (3) memiliki tata tertib sekolah, (4) membiasakan warga sekolah untuk berdisiplin, (5) membiasakan warga sekolah untuk berdisiplin, (6) menegakkan aturan dengan memberikan sanksi secara adil bagi pelanggar tata tertib sekolah. Indikator di kelas meliputi: (1) membiasakan mematuhi aturan, (2) menggunakan pakaian praktik sesuai dengan program studi keahliannya, (3) penyimpanan dan pengeluaran alat dan bahan (sesuai program studi keahlian). Disiplin adalah sikap siswa yang menunjukkan ketaatan dan kepatuhan terhadap peraturan yaitu tata tertib yang dilakukan dengan senang hati dan kesadaran diri. Sedangkan tata tertib adalah kumpulan aturan-aturan yang dibuat secara tertulis dan mengikat dilingkungan sekolah, dan harus dipatuhi setiap warga sekolah sebagai tempat berlangsungnya proses belajar mengajar, ini berarti tata tertib di SD se-Gugus I Gusti Ngurah Jelantik juga menjadi salah satu acuan dalam pembuatan indikator disiplin belajar.

Berdasarkan penjelasan tersebut dapat disimpulkan bahwa disiplin belajar memiliki lima indikator utama yaitu; (a) Disiplin dalam masuk sekolah; (b) Disiplin dalam mengikuti pelajaran disekolah; (c) Disiplin dalam mengerjakan tugas; (d) Disiplin belajar di rumah; (e) Disiplin dalam mentaati tata tertib di sekolah. 
Selain disiplin belajar, faktor lainnya yang mempengaruhi pengetahuan siswa adalah interaksi sosial. Interaksi sosial yang baik memiliki pengaruh yang baik pula bagi kehidupan dan pola pikir siswa tersebut. Bonner (dalam Santosa 2006:11) menyatakan "interaksi sosial adalah suatu hubungan antara dua orang individu atau lebih, dimana tingkah laku individu yang satu mempengaruhi, mengubah atau memperbaiki tingkah laku individu yang lain atau sebaliknya". Interaksi sosial adalah suatu proses hubungan yang dinamis dan saling pengaruhmempengaruhi antar manusia (Suranto, 2011). Rusdiyanta, dkk (2009:26) mengungkapkan bahwa "interaksi sosial merupakan hubungan-hubungan antara orang-orang perorangan, dengan kelompok manusia". Berdasarkan uraian tersebut, dapat disimpulkan bahwa interaksi sosial adalah hubungan antar dua orang atau lebih yang bisa dilakukan tidak dengan cara berkomunikasi atau tatap muka saja, dan dapat mengubah atau memperbaiki tingkah laku individu yang lain atau sebaliknya.

Dalam melakukan interaksi sosial terdapat aspek-aspek yang mempengaruhinya. Menurut Santosa (2006:11) ada empat aspek dalam interaksi sosial, aspek - aspek dalam interaksi sosial adalah adanya hubungan, ada individu, ada tujuan, adanya hubungan dengan struktur dan fungsi kelompok. Selaian aspek-aspek tersebut ada juga faktor yang berpengaruh dalam interaksi sosial. Faktor-faktor tersebut yaitu, (1) Situasi sosial itu bagaimanapun memberi bentuk tingkah laku terhadap individu yang berada dalam situasi tersebut, (2) Kekuasaan norma-norma kelompok sangat berpengaruh terhadap terjadinya interaksi sosial antarindividu, (3) Masingmasing individu memiliki tujuan kepribadian sehingga berpengaruh terhadap tingkah lakunya, (4) Setiap individu berinteraksi sesuai dengan kedudukan dan kondisinya yang bersifat sementara, (5) Setiap situasi mengandung arti bagi setiap individu sehingga hal ini mempengaruhi individu untuk melihat dan menafsirkan situasi tersebut.

Interaksi sosial dapat berpengaruh dalam meningkatkan suatu pemahaman konsep IPS yang dimiliki siswa, karena dalam setiap berinteraksi sosial seorang siswa dapat menemukan informasi yang baik maupun buruk, tergantung cara siswa tersebut memahaminya. Interaksi sosial pada umumnya diukur menggunakan indikator. Menurut Listriana (2016) ada delapan indikator dalam pembentukan interaksi sosial, indikator tersebut yaitu; (a) Percakapan; (b) Saling pengertian; (c) Bekerja sama; (d) Keterbukaan; (e) Empati; (f) Memberikan dukungan; (g) Rasa positif; (h) Adanya kesamaan dengan orang lain.

Selain masalah-masalah tersebut, di sekolah masih banyak terdapat siswa yang bermain sendiri dan tidak mau berkomunikasi dengan teman sebayanya serta rasa kerja sama antar siswa terlihat kurang. Aturan yang di buat oleh sekolah pun di langgar oleh beberapa siswa dan membuat proses pembelajaran menjadi tidak kondusif serta komitmen siswa untuk belajar sangat rendah sehingga membuat pemahaman konsep IPS siswa tersedut pada taraf rendah. Penelitian ini bertujuan untuk mengetahui (1) pengaruh yang signifikan disiplin belajar terhadap pemahaman konsep IPS dan besaran determinasinya (2) pengaruh yang signifikan dan interaksi sosial terhadap pemahaman konsep IPS dan besaran determinasinya (3) pengaruh yang signifikan disiplin belajar dan interaksi sosial terhadap pemahaman konsep IPS siswa kelas V Gugus Gusti Ngurah Jelantik Kecamatan Denpasar Utara tahun ajaran 2018/2019 dan besaran determinasinya. Hasil dalam penelitian ini diharapkan dapat bermanfaat dalam mengembangkan kajian ilmu pengetahuan khususnya di bidang ilmu pendidikan yang terdapat kaitannya dengan disiplin belajar dan interaksi sosial.

\section{Metode}

Penelitian ini dilaksanakan pada siswa kelas V SD Gugus I Gusti Ngurah Jelantik Kecamatan Denpasar Utara menggunakan rancangan penelitian non eksperimen (expost facto). Pada penelitian, expost facto merupakan penelitian di mana variabel-variabel bebas telah terjadi ketika peneliti mulai dengan pengamatan variabel terikat dalam suatu penelitian, yang keterkaitan antarvariabel bebas dengan variabel bebas, maupun variabel bebas dengan variabel terikat sudah terjadi secara alami dan peneliti ingin melacak faktor penyebabnya ( Kerlinger dalam Sukardi, 2012). Penelitian ini bertujuan untuk menentukan apakah terdapat pengaruh variabel bebas terhadap variabel terikat. Variabel bebas dalam penelitian ini ada dua jenis yaitu 
Disiplin Belajar dan Interaksi Sosial, sedangkan variabel terikat dalam penelitian ini adalah Pemahaman Konsep IPS siswa kelas V SD. Untuk lebih jelasnya maka digambarkan hubungan variabel sebagai berikut :

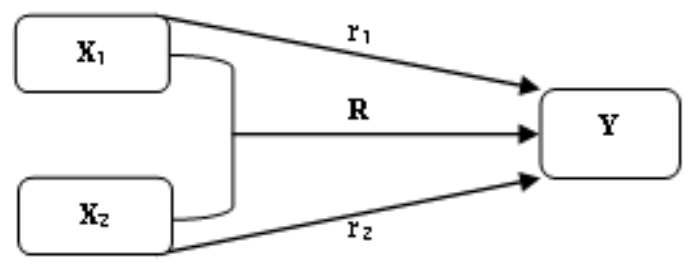

Gambar 1.Paradigma Ganda Dengan dua Variabel independen (Sumber: Sugiyono, 2017) Keterangan:

$\mathrm{X}_{1} \quad=$ Disiplin belajar

$\mathrm{X}_{2} \quad=$ Interaksi sosial

$\mathrm{Y} \quad=$ Pemahaman konsep IPS

$\mathrm{r}_{1} \quad=$ Regresi sederhana $\mathrm{X}_{1}$ terhadap $\mathrm{Y}$

$\mathrm{r}_{2} \quad=$ Regresi sederhana $\mathrm{X}_{2}$ terhadap $\mathrm{Y}$

$\mathrm{R}=$ Regresi ganda $\mathrm{X}_{1}$ dan $\mathrm{X}_{2}$ terhadap $\mathrm{Y}$ (determinasi)

$\longrightarrow=$ Arah regresi

Populasi dalam penelitian ini yaitu seluruh siswa kelas V SD gugus I Gusti Ngurah Jelantik Kecamatan Denpasar Utara, dengan populasi sebanyak 264 siswa yang terdiri dari 8 kelas dalam 4 sekolah dasar.

Menurut Agung (2014:69) "Populasi adalah keseluruhan objek dalam suatu penelitian". Sejalan dengan pendapat tersebut Sugiyono (2015:117) menyatakan, "populasi adalah wilayah generalisasi yang terdiri atas: obyek/subyek yang mempunyai kualitas dan krakteristik tertentu yang ditetapkan oleh peneliti untuk dipelajari dan kemudian ditarik kesimpulannya", dari pengertian tersebut maka dapat dipahami bahwa populasi merupakan seluruh anggota atau objek dalam suatu penelitian yang mempunyai kualitas tertentu yang ditetapkan oleh peneliti untuk dipelajari dan ditarik kesimpulannya.Populasi dalam penelitian ini adalah seluruh siswa kelas V SD Gugus I Gusti Ngurah Jelantik Kecamatan Denpasar Utara Tahun Ajaran 2018/2019. Dari data hasil observasi, diperoleh anggota populasi siswa sebanyak 264 orang.

Penelitian tidak dimungkinkan mempelajari semua yang ada dalam populasi, karena ada keterbatasan seperti dana, tenaga dan waktu, maka dapat digunakan sampel yang diambil dari populasi itu. Sukardi (2012:54) menyatakan "sebagian dari jumlah populasi yang dipilih untuk sumber data tersebut disebut sampel atau cuplikan". Menurut Agung (2014:69) "sampel adalah sebagian dari populasi yang diambil, yang dianggap mewakili seluruh populasi dan diambil dengan menggunakan teknik tertentu".

Berdasarkan uraian tersebut dapat di simpulkan bahwa sampel merupakan sebagian dari jumlah populasi yang dipilih sebagai sumber data, dan dianggap bisa mewakili seluruh populasi yang diambil dengan teknik tertentu.

Teknik penentauan dalam sampel penelitian disebut teknik sampling. Teknik sampling yang digunakan pada penelitian ini adalah probability sampling. Menurut Sugiyono (2017:63) "probability sampling adalah teknik pengambilan sampel yang memberikan peluang yang sama bagi setiap unsur (anggota) populasi untuk dipilih menjadi anggota sampel". Penetapan besaran sampel dapat dilihat pada tabel Issac and Michael. Dalam tabel tersebut terdapat besarnya sampel dari 10 sampai dengan 1.000 .000 dengan tingkat kesalahan 1\%, 5\%, dan $10 \%$ (Sugiyono, 2017), untuk menentukan jenis penelitian dalam bidang pendidikan menggunakan tingkat kesalahan 5\% karena subjek yang digunakan sulit untuk dikontrol secara penuh, maka dari itu tingkat kesalahannya dapat di tolelir sebesar 5\%. Sesuai dengan data dari tabel Issac and Michael dengan jumlah populasi kelas V yang terdapat di gugus Gusti Ngurah Jelantik Denapasar Utara Tahun Ajaran 2018/2019 sebanyak 264 orang. Jumlah sampel yang diambil 
dari populasi tersebut dalam tabel Issac and Michael dengan tingkat kesalahan 5\% adalah 149 orang.

Teknik yang digunakan untuk penentuan sampel adalah proporsional random sampling. Menurut Agung (2014:73) "proporsional random sampling adalah teknik yang digunakan karena unsur populasi berkarakteristik heterogen dan heterogenitas, maka peneliti dapat mengambil sampel dengan cara ini". Teknik proporsional random sampling digunakan untuk mencari berapa banyak sampel yang diambil di setiap sekolah. Berdasarakan jumlah sampel yang telah ditetapkan, kemudian dicari tiap-tiap sampel dari sebaran populasi yang ada di kelas V SD Gugus Gusti Ngurah Jelantik Denpasar Utara Tahun Ajaran 2018/2019 menggunakan teknik proporsional random sampling

Data dikumpulkan menggunakan teknik tes dan juga nontes. Teknik tes digunakan untuk memperoleh data pada pemahaman konsep IPS berupa tes uraian agar dapat menghasilkan data yang interval. Sedangkan teknik non tes digunakan untuk mencari data disiplin belajar dan interaksi sosial yang berupa angket/koesioner agar dapat menghasilkan data yang interval. Sebelum digunakan untuk instrumen penelitian uji coba instrumen dan kemudian diuji validitas butirnya menggunakan korelasi product moment yaitu dengan mengkorelasikan skor tiap butir item dengan skor total. Tes uraian pada pemahaman konsep IPS daari 10 soal pertanyaan diperoleh 8 pertanyaan yang valid sedangkan pada angket disiplin belajar 31 pernyataan yang valid dan interaksi sosial diperoleh 30 pernyataan yang valid dari 35 peernyataan yang diujikan. Keajegan dalam suatu tes diukur menggunakan uji reliabilitas dengan menggunakan rumus Alpha Cronbach.

Data yang diperoleh dalam penelitian dianalisis menggunakan metode analisis statistik inferensial. Sebelum melanjutkan pada analisis regresi linier sederhana dan analisis regresi linier ganda dilakukan uji prasyarat dengan uji normalitas, uji linieritas, uji multikolinieritas, dan uji heterokedastisitas. Pengujian normalitas menggunakan teknik analisis KolmogorovSmirnov dengan bantuan tabel pembanding. Uji multikolinieritas dan heterokedastisitas dihitung menggunakan analisis SPSS 24.0 For Windows. Setelah memenuhi uji prasyarat maka dilanjutkan pada analisis regresi linier sederhana dan analisis regresi linier ganda.

Pengujian hipotesis dilakukan untuk menjawab permasalahan dalam penelitian ini. Hipotesis yang diuji dalam penelitian ini adalah $\mathrm{H}_{\mathrm{o}}$ yang menyatakan bahwa:

1. Tidak terdapat pengaruh yang signifikan disiplin belajar terhadap pemahaman konsep IPS pada siswa Kelas V Gugus I Gusti Ngurah Jelantik Denpasar Utara Tahun Ajaran 2018/2019.

2. Tidak terdapat pengaruh yang signifikan interaksi sosial terhadap pemahaman konsep IPS pada siswa Kelas V Gugus I Gusti Ngurah Jelantik Denpasar Utara Tahun Ajaran $2018 / 2019$.

3. Tidak terdapat pengaruh yang signifikan disiplin belajar dan interaksi sosial terhadap pemahaman konsep IPS pada siswa Kelas V Gugus I Gusti Ngurah Jelantik Denpasar Utara Tahun Ajaran 2018/2019.

\section{Hasil dan Pembahasan}

Data hasil penelitian yang dianalisis adalah data berupa skor, meliputi data disiplin belajar dan interaksi sosial diperoleh melalui pemberian kuesioner, sedangkan data pemahaman konsep IPS diperoleh melalu tes uraian.

Hasil uji prasyarat yang pertama yaitu pada normalitas dengan teknik KolmogorovSmirnov. Sebaran data residu disiplin belajar, interaksi sosial, dan pemahaman konsep IPS dengan menggunakan uji Kolmogorov-Smirnov disajikan dalam tabel berikut:

\section{Tabel 1} Konsep IPS

Hasil Uji Normalitas Residual Disiplin Belajar dan Interaksi Sosial Terhadap Pemahaman 


\begin{tabular}{|c|c|c|c|}
\hline Variabel & $\begin{array}{l}\text { Nilai }\left|\boldsymbol{F}_{\boldsymbol{T}}-\boldsymbol{F}_{\boldsymbol{S}}\right| \\
\text { Terbesar }\end{array}$ & $\begin{array}{c}\text { Nilai Tabel } \\
\text { Kolmogorov-Smirnov }\end{array}$ & Keterangan \\
\hline $\begin{array}{l}\text { Disiplin Belajar } \\
\text { Terhadap Pemahaman } \\
\text { Konsep IPS }\end{array}$ & 0,053 & 0,111 & Berdistribusi Normal \\
\hline $\begin{array}{l}\text { Interaksi Sosial } \\
\text { Terhadap Pemahaman } \\
\text { Konsep IPS }\end{array}$ & 0,060 & 0,111 & Berdistribusi Normal \\
\hline $\begin{array}{l}\text { Disiplin Belajar } \\
\text { dan Interaksi Sosial } \\
\text { Terhadap Pemahaman } \\
\text { Konsep IPS }\end{array}$ & 0,059 & 0,111 & Berdistribusi Normal \\
\hline
\end{tabular}

Berdasarkan hasil yang didapat pada uji normalitas data siswa Kelas V SD Gugus Gusti Ngurah Jelantik menggunakan data normalitas residu diperoleh nilai $\left|F_{T}-F_{S}\right|$ terbesar dari residual disiplin belajar terhadap pemahaman konsep IPS adalah $=0,053$. Dilanjutkan dengan nilai $\left|F_{T}-F_{S}\right|$ terbesar dari residual interaksi sosial terhadap pemahaman konsep IPS $=0,060$. Nilai $\left|F_{T}-F_{S}\right|$ terbesar dari residual disiplin belajar dan interaksi sosial terdahap pemahaman konsep IPS adalah $=0,059<$ yang lebih kecil dari nilai tabel Kolmogorov-Smirnov yaitu $=0,111$ maka demikian dapat dikatakan berdistribusi normal. Data tersebut kemudian dibandingkan dengan $\mathrm{KS}_{\text {tabel }}=0,111$, maka diperoleh data $\mathrm{KS}_{\text {hitung }}$ adalah 0,053, 0,060, 0,05 lebih dari nilai $\mathrm{KS}_{\text {tabel }}$ yaitu 0,111 dengan demikian dapat dikatakan data tersebut berdistribusi normal.

Uji prasyarat yang kedua yaitu uji linieritas data. Data yang diperoleh pada uji linieritas disajikan pada tabel berikut:

\section{Tabel 2}

Hasil Uji Linieritas Garis Regresi Data Disiplin Belajar dan Interaksi Sosial Terahadap Pemahaman Konsep IPS

\begin{tabular}{|c|c|c|c|}
\hline Variabel & F hitung & F tabel & Keterangan \\
\hline $\begin{array}{l}\text { Disiplin Belajar } \\
\text { terhadap Pemahaman } \\
\text { Konsep IPS }\end{array}$ & 1,024 & 1,51 & Linier \\
\hline $\begin{array}{l}\text { Interaksi Sosial } \\
\text { terhadap Pemahaman } \\
\text { Konsep IPS }\end{array}$ & 0,996 & 1,51 & Linier \\
\hline
\end{tabular}

Berdasarkan data tersebut memperoleh hasil pada data disiplin belajar dan pemahaman konsep IPS yaitu $F_{\text {hitung }}=1,024$ lebih kecil dari pada $F_{\text {tabel }}=1,51$ pada taraf signifikan $5 \%$ maka $F$ regresi tersebut linier. Data interaksi sosial dan pemahaman konsep IPS yaitu $\mathrm{F}_{\text {hitung }}=0,996$ lebih kecil dari pada $F_{\text {tabel }}=1,51$ pada taraf signifikan $5 \%$ maka $F$ regresi tersebut linier. berikut:

Uji prasyarat yang ketiga, uji multikolinieritas dengan data yang disajikan pada tabel

\section{Tabel 3}

Hasil Uji Multikolinieritas Disiplin Belajar dan Interaksi Sosial Terhadap Pemahaman Konsep IPS menggunakan program SPSS 24.064 bit for windows.

\begin{tabular}{cccc}
\hline Variabel & Telerance & VIF & Keterangan \\
\hline Disiplin Belajar & 0,987 & 1,013 & Tidak terjadi multikolinieritas \\
Interaksi Sosial & 0,987 & 1,013 & Tidak terjadi multikolinieritas \\
\hline
\end{tabular}

Berdasarkan tabel 3 diketahui bahwa tidak terjadi multikolenieritas karena $\mathrm{X}_{1}$ terhadap $\mathrm{X}_{2}$ nilai Tollerance $=0,987>0,10$ untuk variabel disiplin belajar dan interaksi sosial, sedangkan nilai VIF $=1,013<10$ hal ini berarti bahwa tidak terjadi multikolinieritas antar variabel bebas. Uji Prasyarat yang terakhir adalah uji heterokedastisitas.

Uji prasyarat yang keempat adalah uji heterokedastisitas. Uji heterokedastisitas dengan metode glejser berbantuan program SPSS 24.064 bit for windows disajikan dengan tabel berikut: 


\section{Tabel 4}

Hasil Uji Heteroskedastisitas Disiplin Belajar dan Interaksi Sosial Terhadap Pemahaman Konsep IPS menggunakan program SPSS 24.064 bit for windows.

\begin{tabular}{ccc}
\hline Variabel & Sig. & Keterangan \\
\hline Disiplin Belajar & 0,098 & Tidak terjadi heteroskedastisitas \\
Interaksi Sosial & 0,497 & Tidak terjadi heteroskedastisitas \\
\hline
\end{tabular}

Dari tabel 4 diperoleh nilai signifikansi kedua variabel bebas yaitu disiplin belajar adalah 0,098 lebih dari 0,05 dan interaksi sosial 0,497 lebih dari 0,05, dengan demikian dapat disimpulkan bahwa tidak terjadi masalah heteroskedastisitas pada model regresi.

Hasil uji prasyarat menunjukan data berdistribusi normal dan linier serta pada multikolinieritas dan heterokedastisitas tidak terjadi hubungan, karena uji prasyarat telah terpenuhi maka dapat dilanjutkan pada tahap uji hipotesis.

Pengujian hipotesis pertama dengan analisis regresi sederhana yang memperoleh nilai $\mathrm{F}_{\text {hitung }}=4,389>\mathrm{F}_{\text {tabel }}=3,91$ pada taraf signifikansi $5 \%$ dengan dk pembilang 1 dan dk penyebut 147 maka $F$ regresi tersebut signifikan. Persamaan regresi diperoleh $\hat{Y}=6,550+0,075 X_{1}$ signifikan dan linier, yang berarti bahwa setiap kenaikan 1 kali satuan disiplin belajar menentukan kenaikan 0,075 nilai pemahaman konsep IPS pada konstanta 6,550, sehingga $\mathrm{H}_{0}$ yang menyatakan tidak terdapat pengaruh yang signifikan disiplin belajar terhadap pemahaman konsep IPS siswa Kelas V Gugus I Gusti Ngurah Jelantik Kecamatan Denpasar Utara tahun ajaran 2018/2019 ditolak dan $\mathrm{H}_{\mathrm{a}}$ diterima. Hasil analisis data diperoleh koefisien determinasi $\mathrm{R}^{2}=$ 0,029 dan 2,9\% variasi pemahaman konsep IPS ditentukan oleh disiplin belajar. Hal ini berarti terdapat pengaruh yang signifikan disiplin belajar terhadap pemahaman konsep IPS siswa Kelas V Gugus I Gusti Ngurah Jelantik Kecamatan Denpasar Utara tahun ajaran 2018/2019 dengan determinasi sebesar $2,9 \%$.

Pengujian hipotesis kedua dengan analisis regresi sederhana diperoleh nilai $\mathrm{F}_{\text {hitung }}=4,64>$ $\mathrm{F}_{\text {tabel }}=3,91$ pada taraf signifikan $5 \%$ dengan dk pembilang 1 dan dk penyebut 147 maka $\mathrm{F}$ regresi tersebut signifikan. Persamaan regresi diperoleh $\hat{Y}=7,032+0,070 \mathrm{X}_{2}$ signifikan dan linier, yang berarti bahwa setiap kenaikan 1 kali satuan interaksi sosial menentukan kenaikan 0,070 nilai pemahaman konsep IPS pada konstanta 7,032, sehingga $\mathrm{H}_{0}$ yang menyatakan tidak terdapat pengaruh yang signifikan interaksi sosial terhadap pemahaman konsep IPS siswa Kelas V Gugus I Gusti Ngurah Jelantik Kecamatan Denpasar Utara tahun ajaran 2018/2019 ditolak dan $\mathrm{H}_{\mathrm{a}}$ diterima. Hasil analisis data diperoleh koefisien determinasi $\mathrm{R}^{2}=0,031$ dan 3,1\% variasi pemahaman konsep IPS ditentukan oleh interaksi sosial.. Hal ini berarti terdapat pengaruh yang signifikan disiplin belajar terhadap pemahaman konsep IPS siswa Kelas V Gugus I Gusti Ngurah Jelantik Kecamatan Denpasar Utara tahun ajaran 2018/2019 dengan determinasi sebesar 3,1\%.

Pengujian hipotesis ketiga dengan analisis regresi ganda diperoleh nilai $F_{h i t u n g}=4,12>$ $\mathrm{F}_{\text {tabel }}=3,06$ pada taraf signifikansi $5 \%$ dengan dk pembilang 2 dan dk penyebut 146 maka $\mathrm{F}$ regresi tersebut signifikan. Persamaan regresi diperoleh $\hat{Y}=0,009+0,067 \mathrm{X}_{1}+0,063 \mathrm{X}_{2}$ signifikan dan linier, yang berarti bahwa setiap kenaikan 1 kali satuan disiplin belajar dan interaksi sosial menentukan kenaikan 0,067 dan 0,063 nilai pemahaman konsep IPS pada konstanta 0,009, sehingga $\mathrm{H}_{0}$ yang menyatakan tidak terdapat pengaruh yang signifikan disiplin belajar dan interaksi sosial terhadap pemahaman konsep IPS siswa Kelas V Gugus I Gusti Ngurah Jelantik Kecamatan Denpasar Utara tahun ajaran 2018/2019 ditolak dan $\mathrm{H}_{\mathrm{a}}$ diterima. Hasil analisis data diperoleh koefisien determinasi $\mathrm{R}^{2}=0,053$ dan 5,3\% variasi pemahaman konsep IPS ditentukan secara bersama - sama oleh disiplin belajar dan interaksi sosial. Hal ini berarti tidak terdapat pengaruh yang signifikan disiplin belajar dan interaksi sosial terhadap pemahaman konsep IPS siswa Kelas V Gugus I Gusti Ngurah Jelantik Kecamatan Denpasar Utara tahun ajaran 2018/2019 dengan determinasi sebesar 5,3\%. 


\section{Simpulan}

Berdasarkan analisis yang telah dilaksanakan maka dapat disimpulkan bahwa: (1) Terdapat pengaruh yang signifikan disiplin belajar terhadap pemahaman konsep IPS siswa kelas V Gugus I Gusti Ngurah Jelantik Denpasar Utara Tahun Ajaran 2018/2019, yang dibuktikan berdasarkan nilai $\mathrm{F}_{\text {hitung }}=4,389>\mathrm{F}_{\text {tabel }}=3,91$ pada taraf signifikan $5 \%$ dengan dk pembilang 1 dan dk penyebut 147, dan 2,9\% variasi pemahaman konsep IPS ditentukan oleh disiplin belajar. (2) Terdapat pengaruh yang signifikan interaksi sosial terhadap pemahaman konsep IPS siswa kelas V Gugus I Gusti Ngurah Jelantik Kecamatan Denpasar Utara Tahun Ajaran 2018/2019, yang dibuktikan berdasarkan nilai $\mathrm{F}_{\text {hitung }}=4,64>\mathrm{F}_{\text {tabel }}=3,91$ pada taraf signifikan $5 \%$ dengan dk pembilang 1 dan dk penyebut, dan 3,1\% variasi pemahaman konsep IPS ditentukan oleh interaksi sosial (3) Pengujian hipotesis III menyatakan terdapat pengaruh yang signifikan disiplin belajar dan interaksi sosial terhadap pemahaman konsep IPS siswa kelas V Gugus I Gusti Ngurah Jelantik Kecamatan Denpasar Utara Tahun Ajaran 2018/2019, yang dibuktikan berdasarkan nilai $\mathrm{F}_{\text {hitung }}=4,12>\mathrm{F}_{\text {tabel }}=3,06$ pada taraf signifikansi $5 \%$ dengan dk pembilang 2 dan dk penyebut 146, dan 5,3\% variasi pemahaman konsep IPS ditentukan secara bersamasama oleh disiplin belajar dan interaksi sosial. Dapat dinyatakan bahwa 94,7\% pengaruh terhadap pemahaman konsep khususnya dalam IPS ditentukan oleh faktor selain disiplin belajar dan interaksi sosial. Faktor tersebut diantaranya, kecerdasan emosional, kecerdasan naturalis, rasa ingin tahu,sikap percaya diri, sikap cinta tanah air, kecerdasan interapersonal, motivasi belajar, lingkungan belajar, keluarga, pola asuh dan lainnya. Sebagai tindak lanjut dari hasil penelitian, maka sarankan kepada peneliti lain, hasil penelitian ini dapat dijadikan sebagai salah satu referensi bagi para peneliti dalam bidang pendidikan sebagai bahan untuk mendalami objek penelitian yang sejenis.

\footnotetext{
* Corresponding author.

E-mail Addresses: \{juni.arta.negara, niwayan.suniasih, iwayan.sujana\}@undiksha.ac.id
} 


\section{Daftar Pustaka}

Agung, A. A. Gede. 2014. Metodologi Penelitian Pendidikan. Yogyakarta: Aditya Media Publising

Darmadi, H. 2017. Perkembangan Model Metode Pembelajaran daalam Dinamika Belajar Siswa. Yogyakarta:Budi Utama Grup

Daryanto dan Suryatri Darmiatun. 2013. Implementasi Pendidikan Karakter di Sekolah. Yogyakarta: Gava Media.

Gunawan, Rudy. 2013. Pendidikan IPS. Bandung:Alfabeta

Listriana, Desi. 2016. Hubungan Interaksi Sosial Siswa dengan Hasil Belajar IPS Kelas IV SDN Gugus Dewi Kunthi Kecamatan Gunungpati Kota Semarang. Skripsi (tidak diterbitkan). Jurusan Pendidikan Guru Sekolah Dasar. Universitas Negeri Seamarang.

Ningsih, Sri Yunita. (2017). "Peningkatan Kemampuan Pemahaman Konsep Siswa Melalui Pendekatan Matematika Realistik Di Smp Swasta Tarbiyah Islamiyah". Journal of Mathematics Education and Science, Volume 3, Nomor 1, Tahun 2017

Peraturan Menteri Pendidikan dan Kebudayaan no 21 Tahun 2016 tentang Standar Isi Pendidikan Dasar dan Menengah

Peraturan Menteri Pendidikan Dan Kebudayaan no 22 Tahun 2016 tentang Standar Proses Pendidikan Dasar dan Menengah.

Rusdiyanta, dkk. 2009. Dasar-dasar Sosiologi. Yogyakarta: Graha Ilmu

Santosa, Slamet. 2006. Dinamika Kelompok.Jakarta:PT Bumi Aksara

Sardiman, A.M. 2016. Interaksi dan Motivasi Belajar Mengajar. Jakarta:Pt Raja Grafindo

Sardjiyo, dkk. 2014. Pendidikan IPS di SD. Tangerang:Universitas Terbuka

Sugiyono. 2015. Metode Penelitian Pendidikan. Bandung: Alfabeta

Sugiyono. 2017. Statistika Untuk Penelitian. Bandung: Alfabeta

Sukardi. 2012. Metodologi Penelitian Pendidikan. Jakarta: PT Bumi Aksara

Suranto. 2011. Komunikasi Interpersonal. Yogyakarta: Graha Ilmu.

Susanto. Ahmad. 2013. Teori Belajar dan Pembelajaran di Sekolah Dasar. Jakarta: Kencana Prenadamedia Group

Thobroni, H. 2015. Belajar dan Pembelajaran. Yogyakarta:AR-Ruzz Media 